Tomasz Biernat* ORCID: 0000-0001-7875-0045

Gdańsk

Piotr Krakowiak**, Tomasz Leszniewski***

ORCID: 0000-0002-0500-4954, ORCID: 0000-0002-0458-4934

Toruń

Dagmara Turowska**** ORCID: 0000-0002-9296-5218

Livingston

\title{
Wychowanie religijne dzieci emigrantów zarobkowych jako wyzwanie dla rodziców, duszpasterzy i katechetów (na przykładzie Szkocji)
}

Edukacja religijna w Polsce i w Europie podlega gwałtownym przemianom, podobnie jak życie społeczności, którym służy. Pomijając historyczne

* Dr hab. Tomasz Biernat jest profesorem WSB w Gdańsku. Adres: Instytut Nauk Społecznych i Humanistycznych WSB, ul. Aleja Grunwaldzka 238a, 80-266 Gdańsk; adres e-mail: tomabier@wp.pl.

** Ks. dr hab. Piotr Krakowiak, prof. UMK, jest kierownikiem Katedry Pracy Socjalnej w Wydziale Nauk Pedagogicznych Uniwersytetu Mikołaja Kopernika w Toruniu. Adres: Wydział Nauk Pedagogicznych UMK, ul. Lwowska 1,87-100 Toruń; e-mail: pkrakow@umk.pl.

*** Dr Tomasz Leszniewski jest adiunktem w Katedrze Socjologii Edukacji i Pedagogiki Społecznej w Wydziale Nauk Pedagogicznych Uniwersytetu Mikołaja Kopernika w Toruniu. Adres: Wydział Nauk Pedagogicznych UMK, ul. Lwowska 1,87-100 Toruń; e-mail: tomaszl@, umk.pl.

**** Mgr Dagmara Turowska jest katechetką w Szkole bez Granic im. Niedźwiedzia Wojtka. Adres: St Margaret's Academy, Howden South Road, Livingston, West Lothian, EH546AT; e-mail: maramgad@gmail.com. 
wątki i szczegółowe dyskusje opisane przez Danutę Wajsprych ${ }^{1}$, za podstawową definicję katechezy czy edukacji religijnej przyjmijmy tę zaproponowaną przez papieski dokument Catechesi tradendae:

Katecheza jest wychowaniem w wierze dzieci, młodzieży i dorosłych, a obejmuje przede wszystkim nauczanie doktryny chrześcijańskiej, przekazywane na ogół w sposób systematyczny i całościowy, dla wprowadzenia wierzących w pełnię życia chrześcijańskiego².

Wobec istniejących napięć pomiędzy konfesyjno-katechumenalnym modelem edukacji religijnej, opisanym szczegółowo przez Jerzego Bagrowicza ${ }^{3}$, a realizowanym obecnie $\mathrm{w}$ większości krajów europejskich modelem ponadkonfesyjnym ${ }^{4}$ kompromisowy dla naszych rozważań wydaje się konfesyjno-dialogiczny model zaproponowany w Polsce przez Bogusława Milerskiego ${ }^{5}$. Bogatych informacji o statusie edukacji religijnej w poszczególnych krajach europejskich dostarcza wydany w formie publikacji książkowej w 2007 roku obszerny raport ${ }^{6}$, który nie będzie tu analizowany z powodu charakteru niniejszej pracy. Aniela Różańska przygotowała czytelną tabelę o edukacji religijnej w krajach Unii Europejskiej ${ }^{7}$, z której wynika, iż szkolny system edukacji jest realizowany w różny sposób, zależny od koncepcji państwa i wizji całego systemu nauczania. W Europie edukacja religijna może występować jako:

edukacja religijna separacyjna (model konfesyjno-katechumenalny); edukacja religijna dialogiczna (model konfesyjny, otwarty na dialog pedagogiczny, eku-

${ }^{1}$ Por. Danuta Wajsprych, „Modele edukacji religijnej we współczesnej szkole”, Forum Oświatowe 21 (2009): 78-93.

2 Jan Paweł II, Catechesi tradendae (Watykan, 1979), nr 18.

3 Por. Jerzy Bagrowicz, Edukacja religijna współczesnej młodzieży. Źródła i cele (Torun: Uniwersytet Mikołaja Kopernika, 2000), 275-289.

${ }^{4}$ Jan Charytański, „Lekcje religii w Europie”, Ateneum Kapłańskie 118 (1993): 194-217.

${ }_{5}^{5}$ Bogusław Milerski, Religia a szkoła. Status edukacji religijnej w szkole w ujęciu ewangelickim (Warszawa: Chrześcijańska Akademia Teologiczna, 1998), 273-274. Autor opisuje tam modele: konfesyjno-katechumenalny, ponadkonfesyjny i konfesyjno-dialogiczny, ukazując je jako modele preferowane przez Kościoły w różnych państwach europejskich.

${ }^{6}$ Elza Kuyk, Religious Education in Europe. Situation and current trends in schools (Oslo, 2007).

7 Aniela Różańska, „Edukacja religijna a edukacja międzykulturowa w szkole publicznej w społeczeństwie wielokulturowym", w: Rola religii w edukacji międzykulturowej, red. Wiesława Korzeniowska, Andrzej Murzyn (Kraków: Impuls, 2008), 202-205. 
meniczny i światopoglądowy); edukacja religijna formalnie integracyjna (model ponadkonfesyjny, religioznawczy); edukacja religijna integracyjna (model międzykonfesyjny, ekumeniczny $)^{8}$.

Według Anieli Różańskiej w edukacji religijnej

chodzi o szkołę jako całość, wspólnotę edukacyjną i wychowującą. Szkoła publiczna nie może przedkładać jednego wariantu wychowania nad drugi (chrześcijański nad laicki bądź odwrotnie). Musi też unikać „gettoizacji” i dyskryminacji uczniów wywodzących się z mniejszościowych grup kulturowych i religijnych oraz zapewnić warunki współżycia różnych kultur. $Z$ drugiej strony obowiązkiem szkoły i nauczycieli jest pomaganie rodzicom w „wychowaniu do wartości"’.

Jak wygląda to w przypadku Wielkiej Brytanii, a bardziej szczegółowo w posiadającej autonomię w dziedzinie edukacji - Szkocji10? Na te pytania będziemy się starać znaleźć odpowiedź w artykule łączącym teorię z praktyką edukacyjną wychowania religijnego i katechizacji oraz przeprowadzonymi wśród Polskich rodzin badaniami. Z uwagi na badane środowiska i osobiste doświadczenia badaczy, mówiąc o edukacji religijnej, zajmiemy się w tym artykule wyłącznie katolicką edukacją religijną w Szkocji, gdyż w przypadku badanych Polaków było to dominujące wyznanie.

\section{Katolicka edukacja religijna w Szkocji}

Wyjątkową historię katolickiej edukacji, obchodzącej 100-lecie podpisania Aktu edukacyjnego (Education Act of Scotland) z 1918 roku, zajmującego kluczowe miejsce w historii rozwoju współczesnego sytemu edukacji w tym kraju, opisują liczne publikacje w języku angielskim ${ }^{11}$, a także wydane

8 Tamże, 195-196.

9 Tamże, 197.

${ }^{10}$ Por. https://education.gov.scot/scottish-education-system [dostęp: 30.05.2018]. Edukacja w Szkocji jest nadzorowana przez rząd Szkocji i ma długą historię powszechnej edukacji publicznej, a szkocki system edukacji wyraźnie różni się od systemu w innych krajach Zjednoczonego Królestwa. Ustawa o Szkocji z 1998 roku dała parlamentowi szkockiemu kontrolę ustawodawczą nad wszystkimi kwestiami edukacyjnymi.

11 Por. Tom Fitzpatrick, „Catholic Education in Scotland”, w: Scottish Education: Post-devolution, red. Tom G. K. Bryce, Walter M. Humes (Edinburgh: Edinburgh University 
po polsku ${ }^{12}$. Za badaczami zagadnienia można stwierdzić, że od czasów posoborowych do chwili obecnej w szkockiej edukacji katolickiej trwa „złoty wiek" dla katolików i szkół katolickich. Zyskały one sobie uznanie społeczne w Szkocji, zarówno ze względu na swoje osiągnięcia akademickie, jak i z powodu wysokiego etosu edukacyjnego. Według Dyrektorium dla Diecezji Szkocji z roku 2017 w ośmiu diecezjach katolickich znajduje się 366 katolickich szkół podstawowych i średnich ${ }^{13}$. Odpowiedzialność za przygotowanie nauczycieli katolickich została delegowana przez Konferencję Episkopatu Szkocji do Uniwersytetu w Glasgow, który posiada wydział edukacji katolickiej, szkolący nauczycieli. Zgodnie z Aktem edukacyjnym z roku 1918, odpowiedzialność za utrzymanie szkół katolickich przeszła na lokalne władze, a Kościół ze swojej strony jest odpowiedzialny za kontynuację podtrzymywania katolickiego etosu szkoły. Paradoksalnie jednak, mimo emancypacji społecznej katolików i rozwoju szkół katolickich, Kościół katolicki w Szkocji cierpi z powodu sekularyzmu, który stara się zająć dominujące miejsce w publicznej debacie społecznej na temat edukacji ${ }^{14}$. Najważniejsze kwestie w niej stawiane dotyczą zasadności utrzymywania szkół wyznaniowych oraz ich ewentualnego wpływu na podziały w społeczeństwie ${ }^{15}$. Jednakże od 2004 roku - zarówno w społeczeństwie, jak i w Kościele katolickim - zauważalny jest przypływ nowych wiernych wywodzących się spośród europejskiej emigracji zarobkowej z nowych krajów unijnych, szczególnie z Polski, co

Press, 2003), 274-277; J. H. Treble, „The development of Roman Catholic Education in Scotland 1878-1978", The Innes Review 29 (1978): 111-139.

${ }^{12} \mathrm{~W}$ języku polskim jest dostępna w formie rękopisu praca doktorska: Marcin Motyka, Apostolat szkół katolickich w Szkocji od czasów restauracji hierarchii katolickiej do czasów współczesnych (1878-2013) (Warszawa: Uniwersytet Kardynała Stefana Wyszyńskiego, 2015).

13 Por. Catholic Directory for Scotland. Annual Publication (Glasgow: Bishop's Conference of Scotland, 2017), 427-437.

14 Por. humanism.org.uk/2017/01/04/majority-support-for-end-to-compulsory-religious-observance -in-scottish-schools/ [dostęp: 30.05.2018]. W Szkocji w 2017 roku pojawiły się wysunięte przez humanistów postulaty o zakończeniu obowiązkowego obrzędu religijnego w szkołach, zwłaszcza w odniesieniu do szkół katolickich. Domagają się zmian, wskazując, iż za społeczne pieniądze utrzymywane są religijne szkoły wyznaniowe w Szkocji. Obecnie jest 370 finansowanych przez państwo szkół wyznaniowych: 366 katolickich, 1 żydowska i 3 episkopalne, a 2199 szkół w tym kraju nie jest wyznaniowych.

15 Mało znane w Polsce zagadnienie sektarianizmu w edukacji zostało opisane w pracy: Marcin Motyka, „Sektarianizm zagrożeniem systemu edukacyjnego w świetle doświadczeń ze Szkocji”, Wychowanie na co dzień 1/250 (2015): 7-12. 
potwierdzają brytyjskie badania statystyczne ${ }^{16}$ oraz praktyka duszpasterska w szkockich diecezjach i szkołach ${ }^{17}$.

Terence McLaughlin, porównując szkockie katolickie i państwowe szkoły, zauważa, że w kwestiach religii większość szkół publicznych albo milczy, albo przekazuje informacje o różnych tradycjach religijnych, dając uczniom możliwość do refleksji i własnego osądu ${ }^{18}$. W środowiskach, gdzie szkoły katolickie w Szkocji są pod wpływem prądów liberalnych, religia bywa redukowana do jednej z wielu filozofii życiowych, a katolicyzm przedstawiany jako jedna $z$ dostępnych opcji, obok protestantyzmu, hinduizmu czy buddyzmu. Być może właśnie w związku z tym liberalnym podejściem w części szkół katolickich rodzice z Polski i z innych krajów nowo przyjętych do Unii Europejskiej, żyjący w Szkocji jako emigranci zarobkowi, nie decydują się na wysłanie dzieci do katolickiej szkoły, ale starają się poszukiwać innych sposobów edukacji religijnej. Opis doświadczeń duszpasterskich i katechetycznych będzie ilustracją tych zagadnień.

\section{Katolicka edukacja religijna Polaków w Szkocji}

Dzieci polskich emigrantów zarobkowych zamieszkujących tereny Szkocji realizują obowiązek szkolny w szkołach anglojęzycznych niekatolickich oraz w szkołach katolickich ${ }^{19}$. Szkockie władze edukacyjne wielokrotnie informowały rodziców w języku angielskim i polskim o możliwości bezpłatnego skierowania polskich dzieci do szkół katolickich ${ }^{20}$. Dodatkowo wiele

${ }^{16}$ Por. Anna Krausova, Carlos Vargas-Silva, Scotland: Census Profile. Migration Observatory briefing (Oxford: The Migrations Observatory, 2013), 8; Thomas Ziarski-Kernberg, The Polish community in Scotland (Glasgow: University of Glasgow, 1990).

${ }_{17}$ Por. Magdalena Nowicka, „Transcultural encounters of diversity. The case of Polish presence in UK", w: New Neighbours - on The Diversity Of Migrants 'political Involvement, red. Agata Dziewulska, Anna M. Ostrowska (Warszawa: Uniwersytet Warszawski, 2012), 115-124.

18 Por. Terence H. McLaughlin, „The distinctiveness of Catholic education”, w: Terence H. McLaughlin, Joseph O'Keefe, Bernadette O'Keeffe, The contemporary Catholic school: Context, identity and diversity (London: Falmer Press, 1996), 136-154.

${ }_{19}$ Brakuje danych mówiących o procentowej ilości polskich dzieci korzystających ze szkolnictwa katolickiego w Szkocji. Najczęściej decyzja o wyborze szkoły nie jest związana z jej wyznaniowym lub niewyznaniowym charakterem, ale z bliskością miejsca zamieszkania. Wiele szkół katolickich na terenach zamieszkiwanych przez Polaków w swoich klasach ma większość uczniów pochodzenia polskiego, ale to zagadnienie oczekuje na całościowe zbadanie.

${ }^{20}$ Por. https://sces.org.uk/information-on-catholic-schools-for-polish-children [dostęp: 
z nich uczęszcza na zajęcia do polskich szkół, które odbywają się w piątki po południu oraz najczęściej w soboty ${ }^{21}$. Rodzice motywują swoje działania tym, iż pragną, by ich dzieci nauczyły się języka ojczystego ich rodzin. Część czyni to bardziej świadomie, pielęgnując dwujęzyczność potomstwa w konsekwencji działań edukacyjnych i promocji ${ }^{22}$, innym zależy na tym, by dzieci mogły się „dogadać” z dziadkami, poznały kraj i kulturę miejsca, skąd pochodzą ich rodzice, by otrzymały pełniejsze i dokładniejsze - w ich ocenie - wykształcenie.

Kolejnym ważnym powodem, dla którego rodzice decydują się na uczestnictwo ich dzieci w zajęciach polskich szkół weekendowych, jest to, iż szkoły katolickie w ramach zajęć lekcyjnych prowadzą przygotowanie do sakramentów świętych (spowiedź, pierwsza komunia święta, bierzmowanie) oczywiście w języku angielskim. Szkoły niekatolickie w Szkocji pozbawione są tego elementu edukacji, choć są w nich obowiązkowe zajęcia z religioznawstwa ${ }^{23}$. Polska szkoła jest więc jedynym miejscem, gdzie uczniowie mogą uzupełnić wiedzę religijną albo uczyć się dodatkowo w języku polskim (w przypadku dzieci ze szkół katolickich). Zdarza się, że uczniowie szkoły ze szkockim przygotowaniem do sakramentów i tak uczęszczają na zajęcia polskie, ponieważ rodzice nie wyobrażają sobie przeżywania ważnych dla ich tożsamości religijnej wydarzeń (spowiedź, komunia) inaczej niż w języku polskim.

Edukacja religijna Polaków zamieszkujących w Szkocji ma za zadanie nie tylko kształcić, dostarczać wiedzy, ale także „przymnażać” wiary. To także próba odpowiedzi na pytania egzystencjalne, o tożsamość, tradycję, korzenie, obywatelstwo. Jak zauważa Daria Hejwosz-Gromkowska: „Poruszając problematykę związaną z obywatelstwem, warto zwrócić uwagę, że stanowi ono zmienną konstrukcję społeczną oraz nie wiąże się jedynie z wymiarem

30.05.2018]. Wydano ulotki w języku polskim i angielskim, aby pomóc w doradztwie polskim rodzinom w zakresie dostępności szkół katolickich w Szkocji.

${ }^{21}$ Por. https://szkolabezgranic.org [dostęp: 30.05.2018]. Ucząca w trzech ośrodkach szkoła reklamuje się w następujący sposób: „Nasza sobotnia szkoła to miejsce, gdzie Twoje dziecko ma szansę nauczyć się mówić, pisać, czytać, a także myśleć w języku polskim”.

${ }^{22}$ Por. https://bilingualmind.com/2016/11/09/dwujezycznosc-definicje/Bilingual MindDwujęzyczny Umysł [dostęp: 30.05.2018].

${ }^{23}$ W szkołach niewyznaniowych w Szkocji obowiązkowe są zajęcia o nazwie RME Religious and Moral Education. Są one obowiązkowe w wymiarze 1 godziny w tygodniu w szkole podstawowej i średniej, ale z powodu wielości wyznań uczniów są to najczęściej ogólne zajęcia z religioznawstwa [www.humanism.scot (dostęp: 30.05.2018)]. 
prawnym między jednostką a państwem narodowym"24. W obecnych czasach obywatelstwo to splot działań w sferze ekonomicznejej ${ }^{25}$, ekologicznej ${ }^{26}$, kosmopolitycznej ${ }^{27}$ - to prawa i obowiązki oraz odpowiedzialne działania w tych obszarach ${ }^{28}$. Jakość edukacji w ogóle, a zwłaszcza w sferze edukacji religijnej dzieci i młodzieży, zależy w dużej mierze od priorytetów ustanowionych w tym względzie przez rodziców. Obecnie uważa się, że podstawowym środowiskiem wychowania i edukacji religijnej jest przede wszystkim rodzina, potem Kościół, a następnie szkoła oraz instytucje kulturalno-oświatowe, które podejmują problematykę religijnąa ${ }^{29}$. Stąd nasze zainteresowanie rodzinami, jako najważniejszymi ośrodkami wychowania religijnego dzieci i młodzieży w ogóle, a szczególnie w sytuacji pobytu na emigracji i związanych z nią wyzwań.

Jednym z zadań socjalizacyjnej funkcji rodziny jest wychowanie religijne, choć niektórzy badacze wyodrębniają podfunkcję lub nawet odrębną funkcję religijną rodziny ${ }^{30}$. Wychowanie religijne zaliczane jest do jednej z dziedzin wychowania ${ }^{31}$. W koncepcji wychowania integralnego, które powinno obejmować wszystkie sfery osobowości, wychowanie religijne odgrywa duże znaczenie, jest bowiem bardzo istotne dla kształtowania sumienia człowieka $^{32}$. Wychowanie religijne polega na przekazywaniu wartości chrześcijańskich i opiera się na zasadach życia chrześcijańskiego ${ }^{33}$. Te zadania nabierają zupełnie nowego znaczenia w przypadku rodzin, które znalazły się

${ }^{24}$ Daria Hejwosz-Gromkowska, „Edukacja religijna w Anglii - budowanie spójności społecznej i obywatelskiej w warunkach pluralizmu kulturowego", Studia Edukacyjne 43 (2017): 43-44.

${ }_{25}$ Peter Miller, „Accounting, «economic citizenship» and the spatial reordering of manufacture”, Accounting, Organizations and Society 19 (1994): 15-43.

26 Andrew Dobson, Ecological citizenship (Oxford: Oxford University Press, 2003).

${ }^{27}$ Martha C. Nussbaum, „Patriotism and cosmopolitanism”, Boston Review 5 (1994), http:// bostonreview.net/archives/BR19.5/nussbaum.html [dostęp: 15.05.2018].

${ }^{28}$ Hejwosz-Gromkowska, Edukacja, 44.

${ }_{29}$ Pedagogika. Leksykon PWN, red. Bogusław Milerski, Bogusław Śliwerski (Warszawa: PWN, 2000), 376.

30 Zbigniew Tyszka, Socjologia rodziny (Warszawa: PWN, 1979), 65 i 171.

${ }^{31}$ Mieczysław Łobocki, Teoria wychowania w zarysie (Kraków: Impuls, 2010), 287-288.

32 Jerzy Bagrowicz, „Wychowanie sumienia u podstaw wychowania integralnego”, w: Edukacja wobec dylematów moralnych współczesności, red. Franciszek Adamski, Andrzej M. de Tchorzewski (Kraków: Wydawnictwo Uniwersytetu Jagiellońskiego, 1999), 81-103.

${ }^{33}$ Marian Nowak, „O wartościach chrześcijańskich w wychowaniu”, Kultura i Edukacja 2 (1992): 41-49. 
w obcym kulturowo i religijnie środowisku. Przedstawione dalej badania są pierwszą próbą znalezienia odpowiedzi na dylematy związane $\mathrm{z}$ edukacją religijną dzieci w rodzinach emigrantów zarobkowych.

\section{Założenia badawcze}

Punktem wyjścia do napisania tego artykułu były badania ankietowe, zrealizowane wśród polskich emigrantów zarobkowych na terenie Szkocji w 2017 roku. Ich celem było poznanie społeczno-kulturowych uwarunkowań emigracji zarobkowej. Część pytań ankietowych dotyczyła również problematyki związanej z religijnym funkcjonowaniem emigrantów w kontekście rodziny, parafii oraz szkoły sobotniej, które są główną płaszczyzną oddziaływań wychowania religijnego. W niniejszym artykule postaramy się odpowiedzieć na kilka pytań badawczych: w jaki sposób realizowane jest wychowanie religijne $w$ rodzinach przebywających na emigracji zarobkowej? jakie są główne problemy związane $\mathrm{z}$ wychowaniem religijnym dzieci emigrantów? jaka jest rola rodziców, duszpasterzy i katechetów w wychowaniu religijnym? jakie są zadania parafii i szkoły sobotniej we wspieraniu wychowania religijnego dzieci i młodzieży? Badania realizowano z wykorzystaniem metody sondażu diagnostycznego: przy użyciu ankiety papierowej oraz za pośrednictwem specjalnie przygotowanej strony internetowej dla Polaków w Szkocji, która zawierała identyczne narzędzie $\mathrm{w}$ formie elektronicznej. W badaniach uczestniczyło 627 osób. Ankiety papierowe zwróciło 258 respondentów (Edynburg, Livingston), a w Internecie wypełniło ją dodatkowo 369 osób.

W celu pogłębienia badań zrealizowano także badania terenowe, zawierające elementy metody etnograficznej. $W$ trakcie ich realizacji przeprowadzone zostały dwa wywiady grupowe w Edynburgu (12 osób) i Livingston (8 osób) oraz 12 wywiadów indywidulanych. Badania terenowe obejmowały szereg wizyt studyjnych oraz obserwacji ukazujących funkcjonowanie parafii katolickich, w których spotykają się Polacy oraz wspólnot i grup religijnych działających na ich terenie. Zorganizowano także kilkanaście spotkań z polskimi rodzinami $w$ ich miejscach zamieszkania, w trakcie których przeprowadzono wywiady środowiskowe (Edynburg, Aberdeen, Livingston, Brechin). W ramach badań odbyły się także dwie wizyty w polskiej szkole sobotniej, do której uczęszczają polskie dzieci uczące się języka polskiego i historii i w której prowadzona jest również nauka religii (Livingston). W trakcie prowadzonych badań wzięto pod uwagę także opinie polskich (3) i szkockich księży (3) pracujących w parafiach, do których należą Polacy. Ważnych in- 
formacji na temat nauki religii udzielili nam również polscy katecheci pracujący z dziećmi. Zebrany materiał badawczy pochodzi z wielu źródeł i mamy nadzieję, że ukazuje różne perspektywy analizowanego problemu.

\section{Wychowanie religijne dzieci emigrantów zarobkowych jako wyzwanie dla rodziców}

Wśród różnych rodzajów emigracji można również wyróżnić emigrację rodzinną. Szczególnie po 2004 roku duża część Polaków wyjechała ze swoimi rodzinami za granicę w poszukiwaniu pracy. Szacuje się, że poza granicami kraju przebywa ok. 2,5 miliona emigrantów zarobkowych z polskim obywatelstwem (GUS, 2016). Według danych statystycznych z 2017 roku liczba Polaków w Wielkiej Brytanii przekroczyła 1 milion. Szczególnym i mało zbadanym zjawiskiem jest emigracja rodzinna, gdy na emigracji przebywają rodzice wraz z dziećmi. Zazwyczaj ma ona charakter emigracji etapowej. Najpierw za granicę w poszukiwaniu pracy wyjeżdża delegat rodziny, często ojciec, a po uzyskaniu przez niego względnej stabilizacji zawodowej, finansowej i mieszkaniowej gwarantującej byt rodzinie dołączają do niego pozostali członkowie rodziny. Często to łączenie rodzin jest ich dramatycznym ratowaniem przed rozpadem związanym z próbą życia $\mathrm{w}$ dwóch światach ${ }^{34}$. Z naszych badań wynika, że aż $27 \%$ respondentów przebywało na emigracji wraz ze swoimi rodzinami. Emigracja rodzinna różni się od emigracji indywidualnej tym, że w procesie akulturacji uczestniczy cała rodzina (rodzice i dzieci). Adaptacja do nowego środowiska życia obejmuje zatem cały system rodziny, który musi dostosować się do wielu nowych i obcych nadsystemów. W świetle wyników badań, celem emigracji rodzinnej najczęściej była poprawa bytu rodziny oraz zagwarantowanie lepszej przyszłości dzieciom. Emigracja rodzinna jest korzystniejsza dla funkcjonowania rodziny niż emigracja indywidualna jednego rodzica czy obojga rodziców, bo nie narusza więzi rodzinnych. Jak pokazują przeprowadzone obserwacje, często nawet zacieśnia relacje między członkami rodziny i potęguje ich siły

${ }^{34}$ Por. wiadomosci.wp.pl/emigracja-niszczy-rodzine-polacy-w-wielkiej-brytanii-sarozczarowani- 6031543552132225a [dostęp: 30.05.2018]. „35-letni Marek pochodzi z Lublina, w Londynie mieszka od czterech lat. Teraz już razem z żoną i synem, których sprowadził na Wyspy w ubiegłym roku. - Po trzech latach oddzielnego życia wiedziałem, że aby utrzymać rodzinę, oni muszą przyjechać do mnie, albo ja muszę wrócić od Polski. Dłużej na odległość nie dało się żyć, odbijało się to na psychice mojej i najbliższych". 
niezbędne do zaadaptowania się do nowych warunków życia. Rodzina złożona z rodziców i dzieci (nuklearna, podstawowa), przebywająca wspólnie za granicą, nie jest narażona na rozłąkę i tęsknotę, a w trudnych chwilach stanowi dla siebie źródło wsparcia i pomocy.

Opuszczenie dotychczasowego środowiska życia rodziny stanowi trudne i bolesne doświadczenie, zarówno dla dorosłych, jak i dzieci. Decyzję o emigracji cechuje ryzyko, niepewność i lęk przed nieznanym. Zmiana jednokulturowego środowiska życia na wielokulturowe może być rozpatrywana $\mathrm{w}$ kategoriach szoku kulturowego, doświadczanego przez całą rodzinę $e^{35}$. Jego skutkiem jest zwiększony poziom stresu rodzinnego wszystkich jej członków, który wynika z procesów akulturacyjnych. Jest on tym większy, im słabsze są kompetencje językowe rodziny oraz im bardziej brakuje wsparcia społecznego na emigracji, udzielanego przez innych emigrantów (np. od członków rodziny, znajomych). Wybór przedszkola, szkoły, wejście w nowe środowisko rówieśnicze to problemy zarówno rodziców, jak i dzieci. Stres akulturacyjny związany z wchodzeniem w nową strukturę społeczną i kulturę przeżywają wszyscy członkowie rodziny.

Sytuacja emigracji zmusza do refleksji nad stosunkiem do wiary i w pewnym stopniu go weryfikuje. Obecnie zwraca się uwagę na różne czynniki wpływające na socjalizację religijną, takie jak: ,autorytarność katechizacji, powierzchowność wychowania religijnego w rodzinie, dystans wobec instytucji Kościoła i kleru, nieobecność wartości religijnych w grupach rówieśniczych, często konformistyczne motywacje uczestnictwa w katechizacji”"36. Katolicka religijność i jej formy w Polsce są zdeterminowane przez tradycję i zwyczaje religijne, wynikają często z wpojonych przez rodzinę nawyków i praktyk, które podlegają społecznej kontroli i znajdują swój wyraz w religijnej kulturze obyczajowej ${ }^{37}$. U polskich emigrantów w Wielkiej Brytanii można wskazać trzy możliwe oddziaływania emigracji na wiarę religijną: kontynuacja praktyk religijnych, kwestionowanie wiary i odchodzenie z Kościoła oraz badanie i poszukiwanie wiary w elastyczny i relatywny sposób ${ }^{38}$.

${ }_{35}$ Monika Chutnik, Szok kulturowy - przyczyny, konsekwencje, przeciwdziałanie (Kraków: Universitas, 2007).

${ }^{36}$ Irena Borowik, Procesy instytucjonalizacji i prywatyzacji religii w powojennej Polsce (Kraków: Wydawnictwo Uniwersytetu Jagiellońskiego, 1997), 105.

37 Janusz Mariański, „Ciągłość i zmiana religijnej kultury obyczajowej”, w: Kultura w kręu wartości, red. Leon Dyczewski (Lublin: Towarzystwo Naukowe KUL, 2000), 165-177.

${ }^{38}$ Kerry Gallagher, Marta Trzebiatowska, „Becoming a «real» Catholic: Polish migrants and lived religiosity in the UK and Ireland", Journal of Contemporary Religion 3 (2017): 431-445. 
Emigracja może być bodźcem zarówno do odrzucenia religii, jak i do jej pogłębienia: stawia pytania o wiarę oraz jej formy wyrażania i praktykowania. Nowy kontekst społeczny, w którym nie ma presji społecznej i kontroli, przyczynia się do modyfikowania form religijności oraz sprzyja subiektywizacji i indywidualizacji praktyk religijnych ${ }^{39}$.

Ponad jedna czwarta respondentów (27\%) w naszych badaniach wyraziła opinię, że jej religijność od czasu przyjazdu na emigrację zmalała. W przypadku $40 \%$ badanych poziom praktyk religijnych na emigracji nie zmienił się w stosunku do okresu sprzed wyjazdu do Wielkiej Brytanii. W tej grupie znalazły się także osoby, u których był on wcześniej niski albo określały się jako niewierzące. Emigracja stała się czynnikiem pozytywnej zmiany w przypadku 15\% badanych, którzy uznali, że poziom ich praktyk religijnych wzrósł (choć nie wiadomo, co ta zmiana oznacza). Zdecydowana większość praktykujących badanych (70\%) najczęściej uczęszcza na msze święte odprawiane w języku polskim. Bardzo niewielu z nich decyduje się uczęszczać na msze odprawiane w języku angielskim. Na msze w języku polskim i angielskim uczęszcza zaledwie 5\%, a w języku angielskim jeszcze mniej, bo tylko 3\%. Może to świadczyć, że msza w języku polskim jest czynnikiem sprzyjającym podtrzymaniu praktyk religijnych i łączności z Kościołem. Brak możliwości uczestnictwa we mszy odprawianej w ojczystym języku negatywnie wpływa na częstotliwość praktyk religijnych. Dużą rolę w praktykowaniu wiary odgrywają kompetencje językowe. Nieznajomość angielskiego, przy braku możliwości uczestniczenia w nabożeństwach w rodzimym języku, wpływa na ograniczenie religijności emigrantów.

Starsze dzieci szybko ulegają oddziaływaniu środowiska rówieśniczego, w zdecydowanej większości zupełnie zlaicyzowanego. Rodzice nie zawsze mają świadomość siły odziaływania socjalizacji wtórnej w postchrześcijańskim społeczeństwie, co grozi zeświecczeniem rodzin i stanowi duże ryzyko utraty wiary ich dzieci. Symptomatyczna jest relacja jednej z badanych matek (M. lat 40, trzy córki - 13, 15, 17 lat, Brechin):

Trochę odeszliśmy od kościoła. W szkole dzieci nie mają religii. Msze po polsku są w tylko Dundee. Trzeba tam dojechać. W Brechin msze są tylko po angielsku. Dziewczynki nie chcą na nie chodzić. Wolą pospać w niedzielę. Do kościoła chodzimy, tylko kiedy przyjeżdżają goście z Polski. Przed komunią

39 Sarah Dunlop, Pete Ward, „From Obligation to Consumption in Two-and-a-half Hours: A Visual Exploration of the Sacred with Young Polish Migrants", Journal of Contemporary Religion 3 (2012): 433-451. 
świętą było tylko kilka spotkań po angielsku. Starsze córki mówią, że nie wierzą w Boga. Tylko najmłodsza chce się jeszcze modlić ${ }^{40}$.

Ten przypadek dobrze pokazuje, że emigracja rodziny dla wychowania religijnego dzieci przyniosła negatywne skutki. Odcięcie rodziny od naturalnych zasobów społecznych, wspierających ją w realizacji funkcji religijnej, prowadzi do jej religijnego ,wyziębienia”, a nawet odejścia od wiary. W ateistycznym środowisku, jakim jest Szkocja, brak jest szerszych społecznych oddziaływań za pośrednictwem mediów (telewizja, radio, bilbordy) mówiących o Kościele, religii. Zlaicyzowane środowisko nie sprzyja zaangażowaniu religijnemu i odciąga od wiary.

Wychowanie religijne dzieci sprowadza się głównie do oddziaływań wewnątrz rodziny. Jest pozbawione instytucjonalnego wsparcia i zakorzenienia w szerszej wspólnocie. Wychowanie religijne w ateistycznym świecie jest trudne. Dzieci nie mają kontaktu ze świadkami wiary. Są odseparowane od naturalnego jej przekazu, który płynie ze starszego pokolenia (np. dziadkowie) i wzmacnia wysiłki rodziców. Nie bez znaczenia jest również brak wsparcia ze strony szerszej rodziny, która niekiedy dostarcza ważnych religijnych doświadczeń dla dzieci i młodzieży. Kontakt z wierzącymi krewnymi (dziadkowie, wujkowie, ciocie, kuzyni) stanowi wartościowy bodziec wzmacniający przekonania religijne.

Negatywnym zjawiskiem, wskazującym na odchodzenie od wiary, które da się zaobserwować wśród części rodzin, jest religijność na pokaz - religijność fasadowa. Praktyki religijne są pozorowane przez rodzinę wtedy, kiedy przyjeżdżają dziadkowie albo rodzina z Polski. Aby jak to wyraziła jedna z badanych osób, „nie robić przykrości gościom z Polski”, rodzina uczestniczy w niedzielnej mszy świętej, choć zazwyczaj tego nie robi. Ukrywanie faktu zaniechania praktyk religijnych dokonywane jest w obawie przed reakcją rodziny, co wskazuje na świadomość istnienia kontroli społecznej, obejmującej tę sferę życia oraz istnienia silnej ${ }^{41}$ więzi między pokoleniami. W istocie część rodzin uczęszcza do Kościoła tylko z okazji wizyt bliskich (zazwyczaj w wielkie święta kościelne) albo kiedy same jadą w odwiedziny do kraju.

Emigracja raczej negatywnie oddziałuje na religijność Polaków oraz wychowanie religijne $\mathrm{w}$ ich rodzinach. U części z nich można zaobserwować

40 Tomasz Biernat, wywiad pogłębiony, Brechin, kwiecień 2018 rok.

${ }^{41}$ Leon Dyczewski, Więź między pokoleniami w rodzinie (Lublin: Towarzystwo Naukowe KUL, 2002), 38. 
zobojętnienie religijne, którego wskaźnikiem jest zmniejszenie częstotliwości lub nawet całkowite zaniechanie praktyk religijnych (udział w mszach świętych, przystępowanie do sakramentów, codzienna modlitwa). Część rodzin nie uczęszcza do Kościoła ze względu na nieznajomość języka angielskiego, choć w wielu kościołach, do których mogą uczęszczać Polacy, są dostępne tłumaczenia modlitw na język polski. Ważnym czynnikiem jest odległość od kościoła. Pokonywanie większych dystansów zniechęca i negatywnie wpływa na częstotliwość praktyk religijnych. W przypadku części osób emigracja może prowadzić do osłabienia, a nawet utraty wiary religijnej. Co czwarty $\mathrm{z}$ badanych rodziców wyraził poczucie zagrożenia związane $\mathrm{z}$ utratą na emigracji wiary przez dzieci. Aż $41 \%$ respondentów oczekuje większej pomocy parafii w zakresie rozwoju religijnego dzieci, co świadczy o niezaspokojonej potrzebie wsparcia rodzin w wychowaniu religijnym.

Niektórzy rodzice mają świadomość zagrożeń dla polskości wiary w zateizowanym społeczeństwie. Zdają sobie także sprawę z siły socjalizacji wtórnej, która może być silniejsza niż wychowanie rodzinne. Dobrze oddaje to jedna z relacji rodziców, którzy mają małe dzieci i zdecydowali się na powrót to kraju w obawie przed utratą wiary i polskości: „Wkrótce wracamy do kraju. Boimy się tutejszej szkoły, bo ona przerobi nasze dzieci i zapomną języka polskiego, odejdą od Boga, bo to jest świat bez Boga".

Zapracowani rodzice, bez wsparcia wychowawczego z zewnątrz, są często bezradni wobec oddziaływań zlaicyzowanego świata, w którym żyją ich dzieci, nie są w stanie przeciwstawiać się ateistycznym i antyreligijnym wpływom otoczenia. W większych społecznościach Polaków, gromadzących się wokół parafii proponujących duszpasterstwo w języku ojczystym, podejmuje się działania edukacji religijnej dla dzieci, których opis ukaże typowe działania polskiej edukacji religijnej w Szkocji.

\section{Wychowanie religijne dzieci emigrantów jako wyzwanie dla duszpasterzy}

W literaturze przedmiotu wielokrotnie podkreślano rolę parafii katolickiej w edukacji religijnej dzieci imigrantów, zarówno w perspektywie historycznej wielkich migracji do USA ${ }^{42}$, jak i w przypadku współczesnych ruchów

${ }^{42}$ Marcin Borys, ,Rola polskich parafii rzymskokatolickich w życiu Polonii chicagowskiej w XIX wieku”, Studia Polonijne 30 (2009): 151-171. 
migracyjnych w Europie ${ }^{43}$. Niejednokrotnie jednak lokalne kościoły nie są dostatecznie przygotowane i otwarte na współpracę z migrantami, co dobrze ilustruje badanie w Irlandii. Programy i praktyka duszpasterska irlandzkich instytucji katolickich wobec imigrantów są znikome. Powodowane jest to z jednej strony ogólnym osłabieniem instytucjonalnego Kościoła, a z drugiej strony brakiem doświadczenia, a wedle niektórych autorów obecnym $\mathrm{w}$ irlandzkiej kulturze rasizmem i izolacjonizmem ${ }^{44}$. Wspólnoty religijne w Szkocji zostały znacznie wzmocnione przez falę emigracji w XXI wieku i po raz pierwszy w historii liczba praktykujących w niedziele katolików przewyższa liczbę protestantów chodzących do kościołów w tym kraju ${ }^{45}$. Choć istnieje formalnie duszpasterstwo polonijne w Szkocji, a oficjalna strona internetowa $\mathrm{w}$ języku polskim ${ }^{46}$ informuje wszystkich zainteresowanych o polskich nabożeństwach i innych wydarzeniach duszpasterskich, to jednak wielu z Polaków nie jest objętych tym duszpasterstwem. Msze święte i duszpasterstwo w języku polskim jest dostępne w kilkunastu miejscach w Szkocji ${ }^{47}$.

Centralnym wydarzeniem dla wspólnoty jest niedzielna Eucharystia, a większość działań duszpasterskich skoncentrowanych jest wokół weekendu, gdy większość osób i rodzin ma więcej czasu po dniach związanych z zajęciami w szkole i w pracy. Powszechną formą zaangażowania dzieci w ży-

${ }^{43}$ Por. Wokót problematyki migracyjnej. Kultura Przyjęcia, red. Janusz Balicki, Mariusz Chamarczuk (Warszawa: UKSW, 2013).

${ }^{44}$ Marcin Lisak, „Transformacja Kościoła katolickiego w Irlandii w kontekście emigracji, misji zagranicznych oraz imigracji”, w: Wokót problematyki migracyjnej. Kultura Przyjęcia, red. Janusz Balicki, Mariusz Chamarczuk (Warszawa: UKSW, 2013), 324.

${ }^{45}$ Zob. www.catholicherald.co.ukwww.catholicherald.co.uk/news/2017/04/21/catholicsto-become-largest-group-of-churchgoers-in-scotland/ [dostęp: 30.05.2018]; tylko 9\% procent szkockiej populacji chodzi do kościołów. W ciągu ostatnich 30 lat liczba chrześcijan, którzy uczęszczają do kościoła, zmniejszyła się o połowę. Kościół katolicki nie zmalał tak szybko, jak inne kościoły z powodu fal imigracji. Wielu imigrantów przybyło do Szkocji w ciągu ostatnich 10-15 lat, a Kościół katolicki zbliżył się do nich, proponując odprawianie mszy w języku polskim. Jest to szczególnie widoczne w Aberdeen, gdzie liczba katolików wzrosła w ciągu ostatnich pięciu lat, w dużej mierze z powodu napływu ludności polskiej.

${ }^{46}$ Zob. https://kosciol.org/ [dostęp: 30.05.2018], Polska Misja Katolicka w Szkocji.

47 Zob. https://kosciol.org/ [dostęp: 31.05.2018]. Glasgow i okolice oferują msze św. po polsku w sześciu różnych kościołach, Edynburg i okolice oferuje polskie duszpasterstwo także w sześciu placówkach; poza tym polskie msze są jeszcze w: Dundee, Perth, w dwóch miejscach w Aberdeen, a także na północy kraju w Inverness i w Fort William. Decyzją biskupów kilku polskich księży nie ma w swoich obowiązkach żadnych zajęć duszpasterskich z Polakami, służąc oficjalnie wspólnotom szkockim, choć nieformalnie pomagają oni także wszystkim zgłaszającym się do nich rodakom. 
cie Kościoła są liczne grupy formacyjne. Większość wspólnot wydaje swoje cotygodniowe gazetki parafialne w języku polskim lub w szkockim biuletynie parafialnym ma przestrzeń na podstawowe informacje w języku polskim. Ciekawą inicjatywą polskiej wspólnoty z Edynburga jest prowadzona przez świeckich parafialna gazetka Źródto, zawierająca - obok tematu przewodniego - także przydatne informacje dla katolików poszukujących nabożeństwa lub pomocy duszpasterza. Bardzo pomocny w edukacji religijnej dzieci jest cotygodniowy dodatek dla najmłodszych, pełen kolorowanek, rebusów i innych katechetycznych narzędzi dla rodziców, którzy są zaproszeni do udziału w konkursach dla dzieci. Tygodnik ten jest rozdawany w kościołach i udostępniony online dla tych, którzy z różnych powodów nie mogą być obecni na niedzielnych liturgiach ${ }^{48}$. Najczęściej występującą formą angażowania dzieci i młodzieży w budowanie liturgii są grupy ministrantów, będące tradycyjnie otwarte tylko dla chłopców albo - zgodnie ze szkockimi zwyczajami - przyjmujące do formacji i służby chłopców i dziewczęta. Niektóre wspólnoty w Szkocji organizują dziecięce zespoły muzyczne, włączając najmłodszych do upiększania i pełniejszego przeżywania spotkań w kościele. Niekiedy wspólnoty muszą się opierać na osobach świeckich, w obliczu braku polskiego kapłana lub tylko sporadycznych wizyt we wspólnocie, która wcześniej miała polskiego księdza ${ }^{49}$. W przypadku działań katechetycznych dla dzieci i młodzieży działania te są prawie w całości realizowane przez osoby świeckie, a ich doświadczenia zostaną przedstawione w kolejnej części tego artykułu.

\section{Wychowanie religijne dzieci polskich emigrantów wyzwaniem dla katechetów}

Najważniejsze wyzwanie katechetyczne stanowi przygotowanie do sakramentów pierwszej spowiedzi świętej i pierwszej komunii świętej. W przypad-

${ }^{48}$ Por. https://www.facebook.com/zrodlo.informator/ [dostęp: 31.05.2018]; tam co tydzień można pobrać poszczególne numery do czytania online: http://online.pubhtml5.com/ $\mathrm{etfb} / \mathrm{ruho} / \# \mathrm{p}=1$ [dostęp: 31.05 .2018 ].

${ }^{49}$ Wspólnota polska w Kirdaldy, po kilku latach obecności polskich księży, otrzymała szkockiego proboszcza, który toleruje działania grupy polonijnej, nie wspierając jej z powodów językowych. Wizyty polskiego księdza z Edynburga pomagają w liturgii, ale wiele ze spraw duszpasterskich i katechetycznych jest realizowanych przez osoby świeckie, we współpracy z polską szkołą sobotnią w tym mieście - por. http://polskaszkolakirkcaldy.org/ [dostęp: 31.05.2018]. 
ku dzieci nieuczęszczających do szkół katolickich odbywa się ono w Szkocji w cyklu dwuletnim. W Livingston oraz w Edynburgu prowadzone jest w języku polskim. Pierwszy rok obejmuje treści przygotowujące dzieci do pierwszej spowiedzi ${ }^{50}$, drugi stanowi kontynuację i uszczegółowienie treści omawianych w pierwszym roku oraz próbę ukazania Kościoła jako miejsca wyjątkowego spotkania z Bogiem: w sakramentach świętych ${ }^{51}$. Dzieci należące do obu grup uczestniczą także w spotkaniach w kościele - tzw. rytach które swoją treścią i formą zaczerpnięte są ze szkockiego przygotowania do sakramentów Christian Initiation for Children (realizowane w ramach szkolnego przygotowania do sakramentów w szkockich szkołach katolickich, ich treści i przebieg dostępne są na stronie internetowej Archidiecezji Edynburg i St. Andrews) ${ }^{52}$.

Grupa przystępujących po raz pierwszy do sakramentu pokuty i pojednania składa się w większości z dzieci w wieku 7-8 lat (w szkockim systemie edukacyjnym odpowiadająca Primary 3; dalej: P3), natomiast dzieci po raz pierwszy w pełni uczestniczące w Eucharystii to ośmio- lub dziewięciolatki (Primary 4; dalej: P4). Dzieci kończące pierwszy rok przygotowań niejako automatycznie stają się członkami grupy P4.

Spotkania przygotowujące do sakramentu spowiedzi świętej dla dzieci nieuczęszczających do szkół katolickich odbywają się co dwa tygodnie i trwają 90 minut, co daje 45 minut tygodniowo. W podobnym trybie spotyka się grupa dzieci komunijnych. Zarówno w Livingston, jak i w Edynburgu zajęcia mają miejsce w budynkach, w których działają sobotnie polskie szkoły. Grupy nie przekraczają 32 osób ze względu na szkockie regulacje zasad bezpieczeństwa ${ }^{53}$.

W tryb katechez szkolnych wplecione zostały spotkania w kościele. Stanowią je wspomniane ryty oraz specjalne katechezy dla rodziców dzieci

${ }^{50} \mathrm{~W}$ pierwszym roku omawiane jest: pojęcie grzechu, Dekalog jako postawa rachunku sumienia, najważniejsze przykazanie, warunki dobrej spowiedzi, nauka formuły spowiedzi świętej w języku polskim i angielskim. Po nieudanej próbie znalezienia podręcznika, który zawierałby wszystkie wymienione treści, opracowane zostały dla obu grup skrypty, gromadzące w jednym miejscu omawiane materiały.

${ }^{51} \mathrm{~W}$ drugim roku następuje szczegółowe omówienie każdego z siedmiu sakramentów.

${ }^{52}$ Zob. www.archdiocese-edinburgh.com/index.php?option=com_content\&view=article\&id=282\&Itemid= 192 [dostęp: 30.04 .2018 ].

${ }^{53}$ Dane na podstawie zajęć ze szkół: Szkoła bez Granic im. Niedźwiedzia Wojtka oddziały w Livingston i Edynburgu, Poloniusz - Mały Instytut Języka Polskiego w Edynburgu, zaraz po zakończeniu oferowanych przez nie podstawowych programowych zajęć (jako zajęcia „dodatkowe”, chętni zostają dłużej w szkole). 
przygotowujących się do obu sakramentów. Każda z grup wiekowych ma spotkania w innym czasie. Obie grupy wiekowe w swoich przygotowaniach realizują także tematy wspólne związane z cyklem liturgicznym Kościoła (święta) oraz lokalnej rzeczywistości (parafia) ${ }^{54}$.

Dzieci biorące udział w zajęciach wprowadzających w życie sakramentalne zobowiązane są do nauczenia się na pamięć modlitw z tak zwanego małego katechizmu ${ }^{55}$. W razie potrzeby (np. w sytuacji chęci przystąpienia do komunii w Polsce), ich znajomość - a także samo uczestniczenie w dwuletnim przygotowaniu - może być udokumentowana zaświadczeniem wystawionym przez duszpasterza.

Ważnym punktem w przygotowaniu do sakramentów dzieci szkolnych jest ich - wraz z rodzicami - udział w rekolekcjach adwentowych i wielkopostnych. Te dodatkowe nauki w kościele nie tylko stanowią uzupełnienie katechezy szkolnej oraz pomagają całym rodzinom w przygotowaniu do ważnych wydarzeń w Kościele, ale także uwrażliwiają dzieci, że dom, szkoła, parafia i Kościół to w zasadzie jedno środowisko formacyjne. Rodzina zaś jest pierwszym - i najważniejszym - miejscem katechizacji młodego pokolenia. Plan rekolekcji zawsze zawiera - oprócz nauk rekolekcyjnych głoszonych przez zapraszanych rekolekcjonistów - tzw. children 's liturgy (liturgie dziecięce). To kolejna pomoc i doskonałe narzędzie do pracy z dziećmi w czasie niedzielnych mszy świętych czy innych spotkań w kościele. Dzieci w wieku szkolnym, w trakcie homilii lub nauk dla dorosłych i młodzieży,

${ }^{54}$ Są nimi zagadnienia dotyczące najważniejszych okresów w roku liturgicznym, jakimi są Adwent oraz Wielki Post. Dzieci w tym czasie poznają tradycje i zwyczaje związane z tymi szczególnymi dniami w życiu Kościoła, ich symbolikę i znaczenie. Obie grupy włączają się wtedy aktywnie w życie parafii i Kościoła, biorąc udział w roratach z lampionami oraz czytając rozważania na drogach krzyżowych. Dodatkowo obie grupy spotykające się w Livingston poznają sylwetki i życiorysy patronów parafii w Livingston (św. Piotra, św. Andrzeja, św. Filipa i św. Teresy z Lisieux), co ma na celu lepsze zrozumienie funkcjonowania tych miejsc $\mathrm{i}$ integrację z ich społecznością. Uczniowie pod koniec roku szkolnego przygotowują krótkie prezentacje na temat swoich patronów, których imię noszą - pomaga to dzieciom poznać świętych Kościoła katolickiego, a zarazem przygotowuje je na świadomy wybór patrona przy bierzmowaniu.

${ }^{55}$ Ojcze nasz, Zdrowaś Maryjo, Chwała Ojcu i Aniele Boży dzieci uczą się w języku polskim i angielskim. W obu tych językach poznają także formułę spowiedzi świętej - pomaga im to w przystępowaniu do sakramentu pokuty i pojednania w sytuacji, gdy nie ma w konfesjonale księdza mówiącego w języku polskim. Dzieci uczą się robić rachunek sumienia w taki sposób, by umieć nazwać grzechy także w języku angielskim. Pozostałe modlitwy i reguły dzieci poznają tylko w języku polskim. 
spotykają się w kaplicy lub holu i te same treści omawiają z katechetkami językiem dostosowanym do wieku odbiorców.

W ramach przygotowań do sakramentów spowiedzi i pierwszej komunii świętej obie grupy otrzymują na samym początku skrypty z materiałami, które spełniają zadanie podręczników ${ }^{56}$. Wymiar godzin oraz specyfika środowiska dzieci dwujęzycznych (a czasem i mówiących kilkoma językami, mających rodziców różnych narodowości, przy czym językiem komunikacji $\mathrm{w}$ domu jest język angielski) wymagają specjalnie dostosowanych materiałów. Żaden z dostępnych na polskim rynku podręczników do nauki religii nie potrafił sprostać potrzebom tej specyficznej grupy odbiorców. Po pierwsze: materiały zawarte w polskich podręcznikach są zbyt obszerne, dostosowane do większej liczby godzin przeznaczonych na katechezę. Przygotowanie do komunii w Polsce rozłożone jest na trzy lata - tu czasu jest znacznie mniej. Po wtóre: trudności językowe odbiorców - często nie tylko w sferze semantycznej, nierzadko nawet $\mathrm{w}$ fonetycznej - wymagają zastosowania materiałów prostych, czytelnych, niemal podstawowych.

Współpraca zespołu katechetek i polskich szkół na terenie Livingston i Edynburga jest odpowiedzią na potrzeby polskiej społeczności zamieszkującej te dwa ośrodki w Szkocji. Rodzice posyłający swoje pociechy na zajęcia języka polskiego do polskich szkół to osoby świadome, iż dwujęzyczność ich pociech jest czymś wyjątkowym, ale także ogromnym wyzwaniem, nie tylko edukacyjnym. Jest to sprawdzian przede wszystkim w wymiarze tożsamości. To próba odpowiedzi na pytanie: kim jestem? Odpowiedź jest w miarę oczywista, jeśli skupimy się na rodzicach. Pamiętają oni bardzo dobrze Polskę: jest to miejsce ich urodzenia, wzrastania i dojrzewania, wejścia w dorosłość. Szkocja staje się ich nowym domem, jednak wiedzą oni, skąd pochodzą. Pytanie to dotyczy znacznie bardziej dzieci z polskich rodzin, nierzadko urodzonych już w Wielkiej Brytanii: kim one są? czym jest dla nich Polska? czym Szkocja? Cytując Jana Pawła II:

Wyraz „ojczyzna” łączy się z pojęciem i z rzeczywistością ojca. Ojczyzna to poniekąd to samo co ojcowizna, czyli zasób dóbr, które otrzymaliśmy w dziedzictwie po ojcach. To znaczące, że wielokrotnie mówi się też: „ojczyzna-matka”. Wiemy z własnego doświadczenia, w jakim stopniu przekaz dziedzictwa duchowego dokonuje się za pośrednictwem matek. Ojczyzna więc to jest dzie-

56 Dla grupy P3 autorem skryptu Przygotowanie do spowiedzi świętej jest Kinga Staszek, dla grupy P4 zaś skrypt Przygotowanie do Pierwszej Komunii świętej opracowała Dagmara Agnieszka Turowska. 
dzictwo, a równocześnie jest to wynikający z tego dziedzictwa stan posiadania - w tym również ziemi, terytorium, ale jeszcze bardziej wartości i treści duchowych, jakie składają się na kulturę danego narodu. O tym właśnie mówiłem w UNESCO 2 czerwca 1980 roku, podkreślając, że wówczas, gdy Polaków pozbawiono terytorium, a naród został podzielony, dziedzictwo duchowe, czyli kultura przejęta przez przodków, przetrwało w nich. Co więcej, wyjątkowo dynamicznie się rozwinęło ${ }^{57}$.

Zapisanie dzieci z polskich lub mieszanych rodzin na zajęcia polskiej szkoły jest niewątpliwie próbą przekazania dzieciom tego dziedzictwa, o którym mówił papież Polak. Dodatkowo dołączenie do cyklu zajęć z języka polskiego, historii i geografii Polski lekcji religii daje szerszą perspektywę tego, co chcą swoim dzieciom przekazać emigrujący z kraju Polacy. Jak stwierdza profesor Zbigniew Marek: „Za obecnością religii w procesach edukacyjnych przemawiają ludzkie wysiłki i dążenia do poznania prawdy. Równocześnie człowiek żyjący w kręgu kultury zachodnioeuropejskiej jest zawieszony między wiarą i niewiarą" "58. Bardzo często, zaraz po wyjeździe z ojczyzny, Polacy kierują swoje pierwsze kroki do kościoła, gdzie spotyka się Polonia, by nawiązać kontakt z rodakami, ale także by w kraju emigracji zachować namiastkę tego, co znają - co kochają: Polski. By nie stracić z oczu priorytetów i wartości, w jakich zostali wychowani - a które tak łatwo zagubić w sekularyzowanej i laickiej rzeczywistości Zachodu. Wielu z nich właśnie w tym dziedzictwie duchowym widzi element zachowujący w nich polskość.

Katecheza dzieci polskojęzycznych spotyka się z wieloma trudnymi zagadnieniami. Kościół jest katolicki, powszechny - zatem polska katecheza nie może być odrębnym, wyizolowanym ideologicznie i praktycznie tworem. Założeniem przygotowania prowadzonego w języku polskim w Livingston i Edynburgu jest także zbliżenie, zintegrowanie polskiego środowiska z lokalnym, szkockim. Podjęte zostały próby organizacji wspólnych uroczystości, uczestnictwo we wspólnych nabożeństwach (na przykład droga krzyżowa, modlitwa różańcowa). Program polskiego przygotowania zawiera elementy szkockich rytów inicjacji chrześcijańskiej. Dzieci uczą się tekstów mszy świętej, spowiedzi, najważniejszych modlitw również w języku angielskim by móc aktywnie uczestniczyć w uroczystościach.

57 Jan Paweł II, Pamięć i tożsamość. Rozmowy na przetomie tysiącleci (Skultuna: Ligatur, 2012), 47.

58 Zbigniew Marek, „Edukacja religijna w poszukiwaniu odpowiedzi na egzystencjalne pytania człowieka", Paedagogia Christiana 2/40 (2017): 12. 
Kolejną trudnością, z jaką spotyka się polska katecheza, jest bariera językowa dotykająca jej uczestników. Większość dzieci zna język polski na poziomie pozwalającym swobodne porozumiewać się nim i korzystać z polskojęzycznych materiałów. Zdarzają się jednak przypadki dzieci, które zdradzają wyraźne trudności językowe, nie tylko w zrozumieniu przekazywanych treści, ale także w swobodnej konwersacji w języku ojczystym ich rodziców. Wyraźnie widać, iż dla znacznej większości z nich pierwszym językiem komunikacji jest już angielski. Problem ten stanowi nie tylko wyzwanie w pracy z dziećmi związanej z konwersacją czy przekazywaniem treści, ale także $\mathrm{w}$ dostosowaniu i przygotowaniu materiałów do pracy.

Ważnym elementem oceny stanu przygotowania do sakramentów jest poziom świadomości religijnej dzieci wyniesiony z domu rodzinnego oraz motywacja do polskojęzycznego przygotowania dzieci do sakramentów spowiedzi i komunii świętej. Podczas pracy z dziećmi wyraźnie widać, które rodziny są zaangażowane religijnie w życie lokalnego Kościoła i parafii. Świadczy o tym na przykład znajomość podstawowych modlitw, które składają się na codzienny pacierz czy są odmawiane podczas każdej mszy świętej (np. Ojcze nasz). Także obecność dzieci na liturgiach dziecięcych jest oczywistym dowodem obecności rodzin na coniedzielnych praktykach religijnych. Praca z dziećmi z rodzin bardzo aktywnie zaangażowanych w życie religijne, będących członkami wspólnot świeckich (takich jak Kościół Domowy, Droga Neokatechumenalna czy różne wspólnoty modlitewne), sprawia, że problemy poruszane na zajęciach i pytania zadawane przez dzieci daleko wykraczają poza podstawowy rys zajęć, jaki możliwy jest do zrealizowania w tym wymiarze godzinowym polskojęzycznej katechezy. Część sygnalizowanych przez te dzieci dodatkowych treści realizowana jest podczas wspomnianych już liturgii dziecięcych, a także w ramach dodatkowych zadań domowych, do których zachęcane są najbardziej aktywne i zaangażowane dzieci. Wymagają one pracy z rodzicami, ich większej uwagi i pomocy. Dzięki temu w przygotowanie religijne włączeni są inni członkowie rodziny: rodzice, rodzeństwo. W takich przypadkach katecheza jest tylko uzupełnieniem, dodatkiem i pomocą w religijnym życiu rodziny - nie zaś jego jedynym organizatorem.

\section{Zakończenie}

Funkcja religijna współczesnej rodziny i wynikające z niej wychowanie religijne obecnie ulega przemianom, co najczęściej wynika z tego, że rodzi- 
ce nie mają czasu, by przekazać dzieciom wiedzę religijną oraz że zanikają świadectwa wiary w życiu codziennym (wspólna modlitwa, czytanie Pisma Świętego, uczęszczanie do kościoła) ${ }^{59}$. Oczywiście zmiany te w dużej mierze zależą od świadomości religijnej rodziców. Negatywnym czynnikiem osłabiającym wiarę i praktyki religijne młodego pokolenia jest oddziaływanie mediów i kultury popularnej, które w dzisiejszych czasach podważają sens religii, a niekiedy przekazują treści o antyklerykalnym czy wręcz antyreligijnym charakterze. Sytuacja emigracji zarobkowej stanowi dodatkowe wyzwanie dla funkcji religijnej rodziny i wychowania religijnego dzieci. Przebywanie rodziny poza granicami kraju i poza jej naturalnym środowiskiem, które często wzmacnia oddziaływania wychowawcze rodziców w zakresie wychowania religijnego (katecheza w szkole, katolickie media, wzorce religijne dziadków, dalszej rodziny, rówieśników), utrudnia wychowanie i edukację religijną dzieci. W opinii jednej trzeciej badanych rodziców funkcjonowanie w zsekularyzowanym środowisku na emigracji stanowi zagrożenie dla wychowania religijnego ich dzieci. Należy jednak zauważyć, że dla części badanych rodzin emigracja stała się bodźcem, który mobilizuje do zwiększenia wysiłków wychowawczych w kierunku przekazywania wiary, co przejawia się także wzrostem zaangażowania religijnego rodziców.

\section{Religious Upbringing of Economic Migrants' Children: a Challenge for Parents, Priests and Catechists as Studied in Scotland (Summary)}

The aim of the article was to provide a description of the conditions affecting religious upbringing of children in families that are staying in Scotland during an economic migration. The perspective used encompasses the family environment, the parish, the Scottish educational system and its constituent catholic schools, and a Polish Saturday school. The presented research was conducted among Poles staying in Scotland. It shows that family emigration makes religious upbringing of children harder. We may attribute this to the following main factors: a weakening of the parents' religiosity, a lack of religious education in public schools, insufficient

59 Franciszek Adamski, Rodzina, wymiar społeczno-kulturowy (Kraków: Wydawnictwo UJ, 2002), 148-149. Na temat sekularyzacji rodziny jako instytucji religijnej por. Franciszek Adamski, Edukacja, rodzina, kultura: studia z pedagogiki społecznej (Kraków: Wydawnictwo UJ, 1999), 45-59. 
knowledge of catholic education, a limit of the capability of attending Polish language catholic mass, and a lay environment in which the children operate. A certain challenge for the emigrants is understanding the different character of catholic education in Scotland from that in Poland. A large problem is insufficient catechism activities which are usually ad hoc, limited in duration, and reach only a part of the children and youth. In families with weak religiosity, an emigration threatens the realization of the religious education and upbringing function of families and favors the cessation of faith. Pastoral and catechist activities with a large engagement of lay catechists are an attempt to deal with the challenges that families face with children being raised in dual language environments and cultures of varied attitudes to religious and spiritual needs.

Keywords: religious upbringing; Scotland; economic migration; catholic schools; multicultural education.

\section{Wychowanie religijne dzieci emigrantów zarobkowych jako wyzwanie dla rodziców, duszpasterzy i katechetów (na przykładzie Szkocji) \\ (Streszczenie)}

Celem artykułu była próba opisu uwarunkowań wychowania religijnego dzieci w rodzinach, które przebywają na emigracji zarobkowej w Szkocji. Przyjęta perspektywa obejmuje środowisko rodziny, parafii, systemu edukacyjnego, w który włączona jest edukacja katolicka i polskiej szkoły sobotniej - perspektywy kluczowe dla opisu tego zagadnienia. Prezentowane tu badania przeprowadzone wśród Polaków przybywających w Szkocji wskazują, że emigracja rodzinna utrudnia wychowanie religijne dzieci. Do głównych czynników, które przyczyniają się do tego stanu rzeczy, można zaliczyć: osłabienie religijności rodziców, brak religii w szkołach publicznych, niewystarczająca wiedza na temat edukacji katolickiej, ograniczenie możliwości uczestniczenia w mszach katolickich odprawianych w języku polskim oraz laickie otoczenie, w którym funkcjonują dzieci. Wyzwaniem jest zrozumienie różnego charakteru katolickiej edukacji w Szkocji i w Polsce. Dużym problemem jest również niewystarczająca katechizacja, która ma zazwyczaj charakter doraźny, ograniczony czasowo oraz obejmuje jedynie część dzieci i młodzieży. W rodzinach o słabej religijności emigracja zagraża realizacji funkcji religijnej rodziny i wychowaniu religijnemu dzieci oraz sprzyja odchodzeniu od wiary. Działania pastoralno-katechetyczne z dużym zaangażowaniem świeckich katechetów są próbą odpowiedzi na wyzwania, 
stojące przed rodzinami i dziećmi wychowującymi się w dwujęzycznych środowiskach i w kulturach o różnym nastawieniu do potrzeb religijnych i duchowych.

Słowa kluczowe: wychowanie religijne; Szkocja; migracja zarobkowa; szkoły katolickie; edukacja międzykulturowa.

\section{Bibliografia}

Adamski, Franciszek. Edukacja, rodzina, kultura: studia z pedagogiki społecznej. Kraków: Wydawnictwo UJ, 1999.

Adamski, Franciszek. Rodzina, wymiar społeczno-kulturowy. Kraków: Wydawnictwo UJ, 2002.

Bagrowicz, Jerzy. Edukacja religijna współczesnej młodzieży. Źródła i cele. Torun: Uniwersytet Mikołaja Kopernika, 2000.

Bagrowicz, Jerzy. „Wychowanie sumienia u podstaw wychowania integralnego”. W: Edukacja wobec dylematów moralnych wspótczesności, red. Franciszek Adamski, Andrzej M. de Tchorzewski, 81-103. Kraków: Wydawnictwo Uniwersytetu Jagiellońskiego, 1999.

Borowik, Irena. Procesy instytucjonalizacji i prywatyzacji religii w powojennej Polsce. Kraków: Wydawnictwo Uniwersytetu Jagiellońskiego, 1997.

Borys, Marcin. „Rola polskich parafii rzymskokatolickich w życiu Polonii chicagowskiej w XIX wieku”. Studia Polonijne 30 (2009): 151-171.

Catholic Directory for Scotland. Annual Publication. Glasgow: Bishop's Conference of Scotland, 2017.

Charytański, Jan. „Lekcje religii w Europie”. Ateneum Kapłańskie 118 (1993): 194-217 .

Chutnik, Monika. Szok kulturowy - przyczyny, konsekwencje, przeciwdziałanie. Kraków: Universitas, 2007.

Dobson, Andrew. Ecological citizenship. Oxford: Oxford University Press, 2003.

Dunlop, Sarah, Pete Ward. „From Obligation to Consumption in Two-and-a-half Hours: A Visual Exploration of the Sacred with Young Polish Migrants". Journal of Contemporary Religion 3 (2012): 433-451.

Dyczewski, Leon. Więź między pokoleniami $w$ rodzinie. Lublin: Towarzystwo Naukowe KUL, 2002.

Fitzpatrick, Tom. „Catholic Education in Scotland”. W: Scottish Education: Postdevolution, red. Tom G. K. Bryce, Walter M. Humes, 272-281. Edinburgh: Edinburgh University Press, 2003. 
Gallagher, Kerry, Marta Trzebiatowska. „Becoming a «real» Catholic: Polish migrants and lived religiosity in the UK and Ireland". Journal of Contemporary Religion 3 (2017): 431-445.

Hejwosz-Gromkowska, Daria. „Edukacja religijna w Anglii - budowanie spójności społecznej i obywatelskiej w warunkach pluralizmu kulturowego". Studia Edukacyjne 43 (2017): 43-60.

Jan Paweł II. Pamięć i tożsamość. Rozmowy na przełomie tysiącleci. Skultuna: Ligatur, 2012.

Krausova, Anna, Carlos Vargas-Silva. Scotland: Census Profile. Migration Observatory briefing. Oxford: The Migrations Observatory, 2013.

Kuyk, Elza. Religious Education in Europe. Situation and current trends in schools. Oslo, 2007.

Lisak, Marcin. „Transformacja Kościoła katolickiego w Irlandii w kontekście emigracji, misji zagranicznych oraz imigracji”. W: Wokół problematyki migracyjnej. Kultura Przyjęcia, red. Janusz Balicki, Mariusz Chamarczuk, 311-327. Warszawa: Uniwersytet Kardynała Stefana Wyszyńskiego, 2013.

Łobocki, Mieczysław. Teoria wychowania w zarysie. Kraków: Impuls, 2010.

Marek, Zbigniew. „Edukacja religijna w poszukiwaniu odpowiedzi na egzystencjalne pytania człowieka". Peadagogia Christiana 2/40 (2017): 11-32.

Mariański, Janusz. „Ciągłość i zmiana religijnej kultury obyczajowej”. W: Kultura w kręgu wartości, red. Leon Dyczewski, 165-177. Lublin: Towarzystwo Naukowe KUL, 2000.

McLaughlin, Terence H. „The distinctiveness of Catholic education”. W: Terence H. McLaughlin, Joseph O'Keefe, Bernadette O'Keeffe, The contemporary Catholic school: Context, identity and diversity, 136-154. London: Falmer Press, 1996.

Miller, Peter. „Accounting, «economic citizenship» and the spatial reordering of manufacture". Accounting, Organizations and Society 19 (1994): 15-43.

Milerski, Bogusław. Religia a szkoła. Status edukacji religijnej w szkole w ujęciu ewangelickim. Warszawa: Chrześcijańska Akademia Teologiczna, 1998.

Motyka, Marcin. Apostolat szkót katolickich w Szkocji od czasów restauracji hierarchii katolickiej do czasów współczesnych (1878-2013). Warszawa: Uniwersytet Kardynała Stefana Wyszyńskiego, 2015 (maszynopis).

Motyka, Marcin. „Sektarianizm zagrożeniem systemu edukacyjnego w świetle doświadczeń ze Szkocji”. Wychowanie na co dzień 1/250 (2015): 7-12.

Nowak, Marian. „O wartościach chrześcijańskich w wychowaniu”. Kultura i Edukacja 2 (1992): 41-49.

Nowicka, Magdalena. „Transcultural encounters of diversity. The case of Polish presence in UK". W: New Neighbours - on The Diversity Of Migrants' political 
Involvement, red. Agata Dziewulska, Anna M. Ostrowska, 115-124. Warszawa: Uniwersytet Warszawski, 2012.

Nussbaum, Martha C. „Patriotism and cosmopolitanism”. Boston Review 5 (1994). http://bostonreview.net/archives/BR19.5/nussbaum.html [dostęp: 15.06.2018]. Pedagogika. Leksykon PWN, red. Bogusław Milerski, Bogusław Śliwerski. Warszawa: PWN, 2000.

Różańska, Aniela. „Edukacja religijna a edukacja międzykulturowa w szkole publicznej w społeczeństwie wielokulturowym". W: Rola religii w edukacji międzykulturowej, red. Wiesława Korzeniowska, Andrzej Murzyn, 193-206. Kraków: Impuls, 2008.

Treble, J. H. „The development of Roman Catholic Education in Scotland 1878-1978". The Innes Review 29 (1978): 111-139.

Tyszka, Zbigniew. Socjologia rodziny. Warszawa: PWN, 1979.

Wajsprych, Danuta. „Modele edukacji religijnej we współczesnej szkole”. Forum Oświatowe 21 (2009): 78-93.

Ziarski-Kernberg, Thomas. The Polish community in Scotland. Glasgow: University of Glasgow, 1990. 
